\title{
THE DESERTIFICATION OF A BASS STRAIT ISLAND AND A PLAN FOR ITS RECOVERY: THE CASE OF EAST KANGAROO ISLAND, FURNEAUX GROUP
}

\author{
by Stephen Harris and Stephen Summers
}

(with two tables, four text-figures, three plates and two appendices)

Harris, S. \& Summers, S., 2000 (31:xii): The desertification of a Bass Strait Island and a plan for its recovery: the case of East Kangaroo
Island, Furneaux Group. Pap. Proc. R. Soc. Tasm. 134: 83-90. ISSN 0080-4703. Nature Conservation Branch and Parks and
Wildlife Service, Department of Primary Industries, Water and Environment, GPO Box 44A, Hobart, Tasmania, Australia 7001.

East Kangaroo Island is a low, mostly calcarenite-covered granitic island in the Furneaux Group which was observed in 1828 to have been fertile and well-wooded by Allocasuarina verticillata. Over 160 years of grazing and a succession of drought years have contributed to the decline of the native vegetation in biomass, ground cover and native species diversity. In the summer of 1999/2000, bare ground comprised $80 \%$ of the island, and the sparse vegetation mostly consisted of heavily browsed exotic grasses and herbs. The meagre flora of 91 taxa comprises $45 \%$ introduced species. The increased exposure from lack of vegetative cover has assisted the salt-wind-tolerant $A$ Astrostipa stipoides to spread inland, particularly from the west coast. An evaluation of the biomass puts the island within the range of that recorded for semi-arid deserts. Stock were removed in early 2000, and methods to restore the vegetation are proposed.

Key Words: flora, Furneaux Group, desertification, East Kangaroo Island, Nature Reserve, conservation, weeds, revegetation, ecological history, sheep-grazing impact, biomass, Cape Barren Goose management, muttonbird, Tasmania.

\section{INTRODUCTION}

East Kangaroo Island is a low-lying, granitic island $11 \mathrm{~km}$ southwest and windward of Whitemark on Flinders Island, situated at $147^{\circ} 54^{\prime}$ longitude and $40^{\circ} 11^{\prime}$ latitude. Comprising $144 \mathrm{ha}$, the island has had a long history of human activity, mainly as a grazing island for sheep but also as a venue for muttonbirding.

East Kangaroo Island was proclaimed as a Conservation Area in 1957 because of the value of the island's muttonbird (Puffinus tenuirostris) rookeries. The island was subsequently given the higher status of a Nature Reserve under the National Parks and Wildlife Act 1970 by virtue of Statutory Rule No.1984, 21. Prior to the proclamation of the Nature Reserve, 16 hectares of freehold land, as well as the then existing grazing lease, were purchased by the Government. The purchase and reservation of the island resulted from a recommendation by Pearse (1975). The island was then known to be one of the five most important Cape Barren Goose (Cereopsis novaehollandiae) breeding areas in the Furneaux Group. An agreement was reached to lease back the island for grazing after providing protection for the muttonbird rookeries. The value of the open pasture on the outer islands assists Cape Barren Goose breeding. The persistence of sheep-grazing under leasehold was considered beneficial to preserving the appropriate breeding habitat.

As early as February 1985, however, the Ranger-in-Charge of the Furneaux Group reported that "Kangaroo Island is the least desirable for a goose refuge. The problem is lack of adequate pasture" which he (Mooney 1985) attributed to overstocking in the previous 20 years, free-ranging stock and, since 1982 (a drought year), the poor seasonal conditions for pasture growth. Problems with the condition of the island continued to be raised by subsequent rangers (Arthur 1997, Summers 1998) culminating in the Government-requested destruction of the stock on the island in January 2000 and the commencement of planning for rehabilitation of the island.

The present study was prompted by the need to record the condition of the island at its worst, so as to measure the improvements which, it is hoped, will be achievable in revegetation. The island as a Nature Reserve has at present ceased being of value for its main purpose. There is a need for a strategy for revegetation and recovery which considers any values of the existing biota and environment. The behaviour of weeds and other species under a regime of managed vegetation recovery must also be anticipated.

\section{METHODS}

This study is based on several visits to the island, by ourselves and others. Dr I. Skira and Ms J. Balmer visited the island in April 1989 and recorded by photographs the damaged condition of the island.

(1) The history of grazing and occupation of the island was assembled through primary and secondary sources (e.g. Campbell 1828, Robinson in Plomley 1987, Sim \& Gait 1992).

(2) A vegetation map was prepared from a 1986 black-andwhite aerial photograph which was enlarged to $1: 14000$. Boundaries were checked in the field and the patches assigned to a vegetation type. Comparisons were made with the vegetation on the latest colour aerial photography flown.

(3) A species list was compiled, and the voucher specimens of most species were lodged in the Tasmanian Herbarium (HO). A search of the National Herbarium of Victoria (MEL) was made for specimens from the island. Species occurring on the island were assessed for their nature conservation significance.

(4) The area of vegetation loss was mapped as two classes: severe and degraded. A "severe" classification was applied to the area with less than $300 \mathrm{~kg} / \mathrm{ha}$ biomass and less than $20 \%$ vegetation cover, while "degraded" was applied to areas with less than $50 \%$ cover. Twelve plots of a nominal $30 \mathrm{~m}$ diameter were located in a stratified subjective manner 
throughout the island and cover subjectively assessed within each. The aim was to evaluate cover across the island to verify air photo interpretation.

(5) A transect was located in two sections across the island so as to traverse the range of vegetation on the island. Onesquare-metre plots were located every $100 \mathrm{~m}$ along this transect (fig. 1) yielding 12 plots in which were recorded: soil type, depth, slope, exposure to wind, percentage cover of each species occurring in the plot, and other factors such as whether the plot was in a rookery or not. The percentage cover of the following categories was graphed: (i) bare ground/soil, (ii) bare rock, (iii) dead plant material/litter, (iv) moss, (v) thistle, (vi) mallow, (vii) exotic herbs (Erodium cicutarium, Hypochoeris radicata, Acetosella vulgaris, Plantago coronopus and Euphorbia paralias), (viii) Chenopodium spp, (ix) exotic grasses (Trifolium spp, Agrostis sp, Catapodium rigidum, other exotic Poaceae spp.), (x) native herbs and grasses (Oxalis perennans, Dichondra repens, Geranium potentilloides, Spinifex sericeus), and (xi) Austrostipa stipoides.

(6) The climatic history of the island as far back as 1943 was inferred from records at Whitemark airport. This coastal sea-level station is only $11 \mathrm{~km}$ to the northeast. Outer islands to the west of Flinders Island would be slightly drier, according to BIOCLIM modelling. The annual average rainfall was graphed and two missing data points for the years 1992 and 1993 were substituted by figures for Whitemark Post Office, a similar coastal sea-level station only $3 \mathrm{~km}$ south of the airport station.

(7) An estimate of biomass was achieved by collecting all plant material from seven stratified randomly located $1 \mathrm{~m}^{2}$ quadrats and oven-drying overnight in an AGA oven. The plot size for biomass sampling accords with that proposed for some Central Australian vegetation types (Friedel 1977). Sample frequency is sufficient to give an indicative estimate. The resulting weights were averaged, where there were multiple samples from the same habitat, and extrapolated to give kilograms per hectare for Austrostipa tussock grassland, rookery area, skeletal soils on limestone and limestone pavements and the pasture land on granite. The results were then compared with estimates of biomass in arid rangelands in Central Australia (Friedel \& Bastin 1988, Friedel et al. 1988).

\section{RESULTS}

\section{History of Grazing and Human Activity}

The earliest record of East Kangaroo Island is Campbell's description of 1828 :

$\ldots$ is the most fertile of the whole groupe, and abounds in wood of the sheoak species, the land is low, and at a distance appears like two separate islands, from being almost divided in the centre by a narrow sandy neck, wallaby abound in the thickets, and numbers of muttonbirds and green geese build their nests round the coast ...

By 1832, the island may have been largely cleared. Backhouse, the Quaker missionary, on his voyage among the islands in 1832 (Plomley 1987) stated that

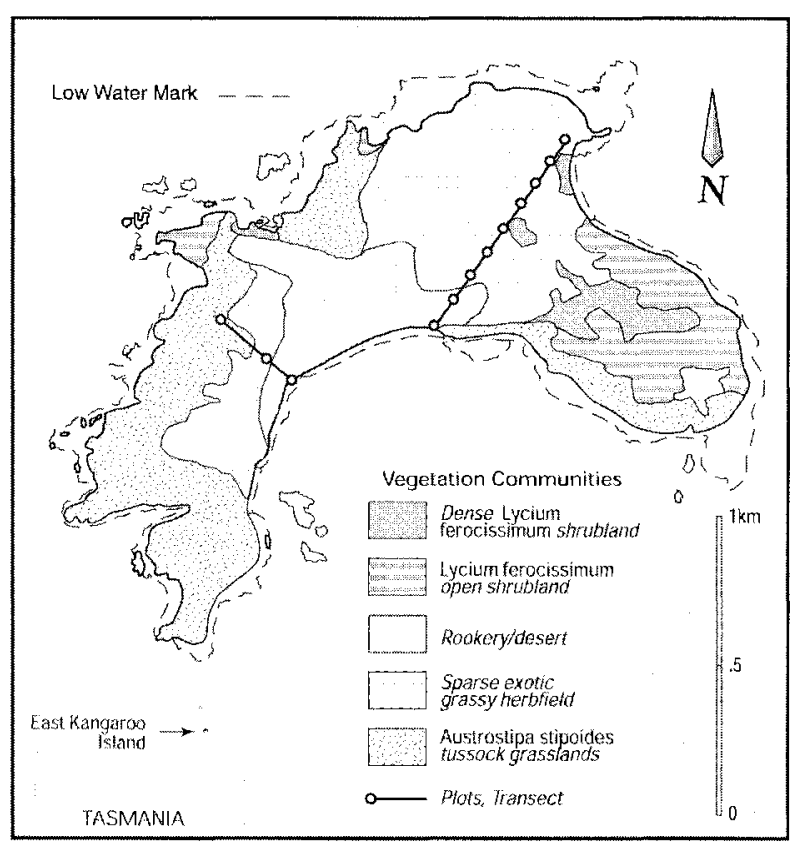

FIG. 1 -Map of the vegetation communities and the location of the transect and plots from which data for this study were drawn.

...we passed Long Island, Badger Island, Chappell Island etc, and came safely to anchor under Green Island, the harbour for the settlement on Flinders... Many of the islands are low and grassy ...

In 1837 , sheep from the Wybalenna settlement were being grazed on the island. Robinson (in Plomley 1987: 482) refers to a shepherd and assistant who were instructed to shear the sheep, weigh the wool and leave it in the men's hut. It seems reasonable to assume fairly continuous grazing until the present day, except that the island seems to have been unoccupied in 1861 , at the time of the visit to the islands by surveyor Thomas, and from local knowledge it was stated to be inferior grazing, covered with barilla and lacking water (Sim \& Gait 1992, Thomas 1861).

Canon Brownrigg visited the island in 1872 and reported (Murray-Smith 1979):

In Kangaroo Island itself, there is nothing remarkable. Its length barely exceeds a mile and a-half, and its breadth about half a mile. Of the few dwarfish trees it ever possessed there remain scarcely half a dozen, and these are strictly preserved for the adornment they afford. Wood, for fuel, has to be boated in from Flinders. At the southern end of the island there is a mutton-bird rookery...

Interestingly, Brownrigg remarks at the same time on the condition of the nearby Green Island claiming that sheep and cattle appeared to thrive in spite of the sterile island, "utterly devoid of timber", no grass being seen except for a short period in spring.

... the entire surface is literally covered with sow thistles, and stinging nettles, with here and there barilla-bushes, and yellow everlastings.

Commercial exploitation of the muttonbird rookery played an important role in the economy of the island up until the 1920 s. Non-commercial muttonbirding continued 
until, in 1990 , the rookery was closed due to degradation and declining harvest.

Baudinet was the occupier from the 1860 s, but James Everett leased the island and at one stage had 300 sheep. In addition to Everett's stock, 60 sheep and 44 lambs are recorded as being grazed by Baudinet (Dr I. Skira, pers. comm.). In about 1876 , the island passed over to the Harley family who then occupied it for two generations until other leaseholders took over pastoral activity on the island in the 1980s. A Flinders Island resident recollected (Griffiths 1927) that

... when the Harley family first went to Kangaroo Island it was a dense mass of scrub and it was some considerable time before they could introduce sheep...

We are uncertain about how to reconcile this statement with the observations of Brownrigg above, but, in any case, by 1884 they are recorded as running 810 sheep and 350 lambs on East Kangaroo Island (Tasm. Parl. Paper 89). In 1974, the Harley family stated that (Harley 1974):

... the island itself consist (sic) of natural pasture is never cultivated as there are considerable limestone rocks on the surface and many muttonbird rookeries, over which a tractor could not safely negotiate as many of these burrows are deep, at present we run between five and seven hundred sheep on it, and rely on the natural rainfall...

The island had a good grass cover around this time (pls 1,2).

Traditional vegetation management on the island has included burning off the Austrostipa stipoides tussocks to allow sheep to graze on intertussock herbs.

\section{The Vegetation}

Five categories have been mapped (fig. 1). The only type of native vegetation remaining is Austrostipa stipoides tussock grassland, which occupies a zone which is exposed to westerly winds. The zone is wider than usual because winds have an unbroken sweep across the island and have extended the competitive advantage of Austrostipa across a wider area. There are two categories of shrubland dominated by Lycium ferocissimum: these may be distinguished according to density but the extensive area of Lycium open shrubland in the southeastern corner of the island has an Austrostipa stipoides lower stratum.

\section{The Flora}

The flora comprises 91 taxa from 36 genera. The best represented genera are Poaceae ( $\mathrm{n}=18$ taxa) and Asteraceae ( $n=10$ taxa). No plants endemic to Tasmania were recorded. The only species listed on the schedules of the Tasmanian Threatened Species Protection Act 1995 is Calystegiasoldanella, which is typically a strandline and foredune plant. It may be a vagrant on the island. Threlkeldia diffusa and Apium insulare are uncommon in Tasmania and are of biogeographic interest. These latter two species occur right on the coast, often in between granite boulders or on cobble beaches. Forty-one taxa are introduced in Tasmania, making $45 \%$ of the total island flora being composed of exotics.

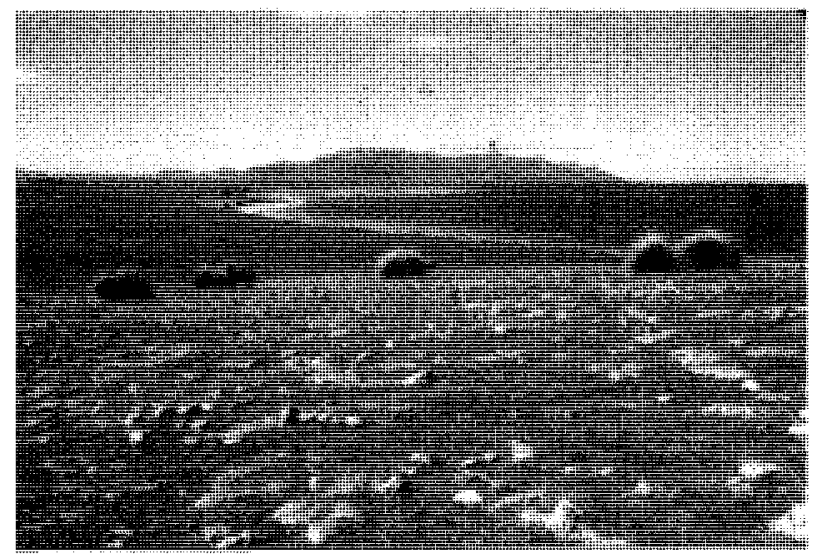

PLATE I

Pasture covers all soil in this photograph taken in 1977. The clumps are Austrostipa stipoides and the foreground is strewn with limestone. Strzelecki Peaks are visible to the east. (Photo: I. Skira.)

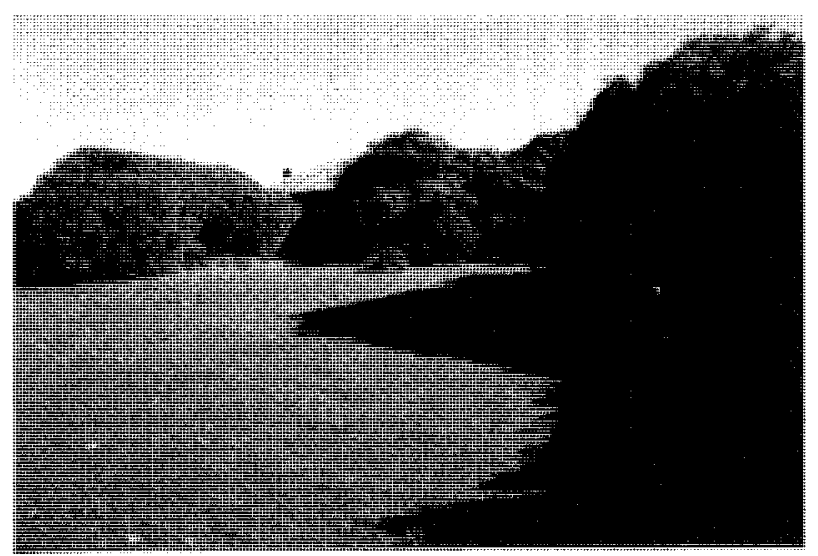

\section{PLATE 2}

In 1977 when this photograph was taken, there was $100 \%$ grass cover where soil was present. Boxthorn (Lycium ferocissimum) is shown here encroaching over much of the land. (Photo: I. Skira.)

\section{Extent of Vegetation Loss}

The vegetation loss is shown in figure 2 . The most extensive loss is on the deepest soils, which are the alkaline sands coinciding with the rookery area. The next worst affected site types are the stony calcarenite areas, where soils are shallow and alkaline. Areas on shallow acid soils on granite have a sparse live vegetation cover but little bare ground obscured largely by dead plant material. Where there are remaining tussocks of native grass, the survival of intertussock herbs appears best.

\section{Species Composition and Cover in Major Habitat Types}

Loss of cover is most marked in the rookery area. The successful survivors appear to be Malva sylvestris, Chenopodium glaucum, Carduus tenuiflorus and Erodium cicutarium. The rocky limestone areas have very poor cover and species diversity. Species in these sites include highly drought tolerant exotic and native herbs: Geranium 


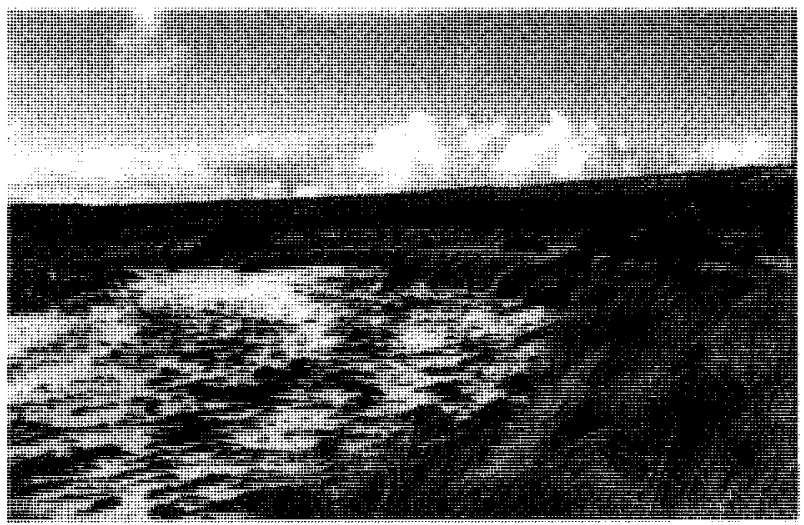

PLATE 3

The coastal belt of Austrostipa stipoides grassland on the south coast of East Kangaroo Island is shown here in 1989. (Photo: I. Skira.)

potentilloides, Plantago coronopus, Dichondra repens, Chenopodium glaucum, Erodium cicutarium and Catapodium rigidum. The Poa tussock areas on shallow acid soils over granite have a high cover of completely dessicated exotic grasses and herbs. Numerous tiny seeds, probably of Trifolium, were observed in some locations within this vegetation type. The Poa poiformis tussocks on the eastern side of the island have become sparse and heavily grazed. In contrast, the Austrostipa stipoides tussocks are dense in many places, and the grazing pressure is less because of the dense and prickly nature of the vegetation (pl. 3). The intertussock flora includes Wahlenbergia sp., Euchiton involucratus, Pseudognaphalium luteo-album, Dichondra repens, Melilotus indica and Epilobium billardierianum. On parts of the western ridge there are clints, grikes and solution holes in the limestone, which provide shaded and protected sites for some of the above species. The Austrostipa stipoides grassland occurring on the frontal sand dunes has a dense root system and the bases of the plants are surrounded by thick deposits of washed/blown up Posidonia australis seagrass and interspersed with Euphorbia paralias.

\section{Climate}

The rainfall records going back to the beginning of the Flinders Island airport station clearly show a prolonged period of below average rainfall in all the years since 1993, including the lowest recorded rainfall year ever in 1997(fig. 3A). The cumulative effect of this moisture deficit is best illustrated in figure $3 \mathrm{~B}$. No other period during the station's record has anywhere near such sustained low rainfall as in this recent period.

\section{Biomass Estimates}

Estimates are tabulated below. They range from a very low $4 \mathrm{~kg}$ per ha on the rookery to about 30 tonnes per hectare in the more dense Austrostipa stipoides grassland. The number of samples collected allow only an indicative estimate.

The biomass recorded for the limestone sands over the flatter central part of the island (rookery) is far lower than that recorded for any of the arid rangeland vegetation types reported from near Alice Springs by Friedel \& Bastin

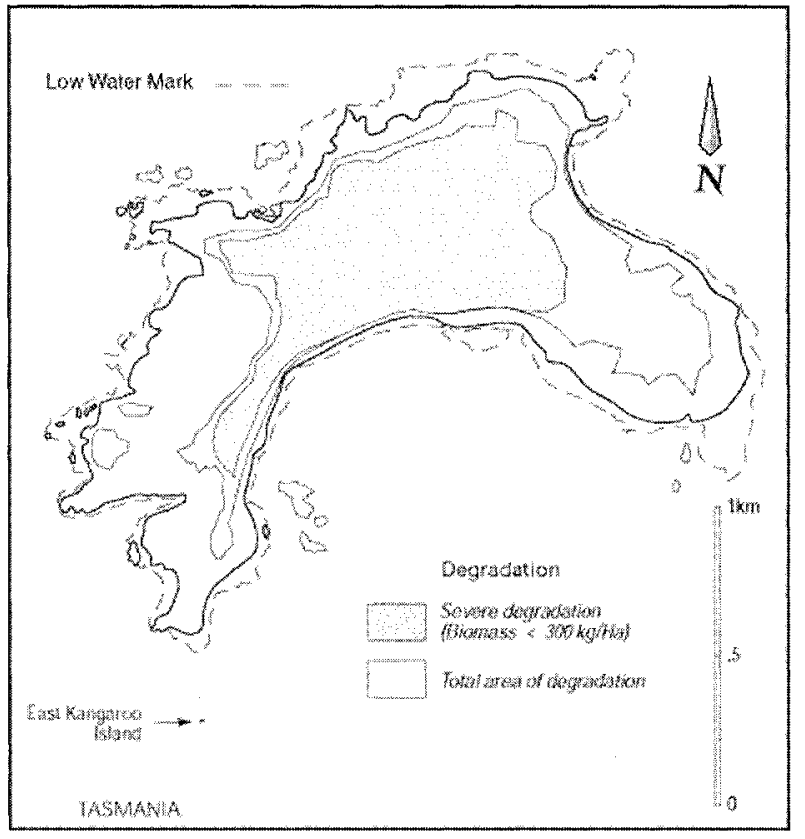

FIG. 2 - Map showing the extent of the degradation of vegetation cover on East Kangaroo Island as at January 2000.

TABLE 1

Biomass estimates for the four principle vegetation habitats on East Kangaroo Island

\begin{tabular}{llc}
\hline Habitat type & $\mathrm{kg} / \mathrm{ha}$ & $\begin{array}{c}\text { Number of } \\
\text { samples }\end{array}$ \\
\hline $\begin{array}{l}\text { Grassland on granite: } \\
\text { scattered Poa poiformis } \\
\text { over dessicated exotics }\end{array}$ & 1330 & $\mathrm{n}=1$ \\
$\begin{array}{l}\text { Skeletal soils on lime- } \\
\text { stone and limestone } \\
\text { pavements }\end{array}$ & 300 & $\mathrm{X}(\mathrm{n}=3)$ \\
$\begin{array}{l}\text { Rookery } \\
\text { Austrostipa stipoides } \\
\text { dominated grassland }\end{array}$ & 30330 & $\mathrm{X}(\mathrm{n}=2)$ \\
\hline
\end{tabular}

(1988). The skeletal soils on limestone and limestone pavements at present support a biomass which is about half that recorded in an arid calcareous shrubby grassland near Alice Springs (Friedel \& Bastin 1998). The Austrostipa stipoides grassland is 30 times the biomass of Mitchell grass plains, the highest yielding of the arid vegetation types recorded.

The alkaline sands and limestone soils are clearly able to support less vegetation on the island in drought conditions than the much more nutrient-poor acid coastal sands and granite soils.

\section{DISCUSSION}

\section{The Processes to the Present}

The island exhibits, in a most dramatic way, the results of processes which have operated on many of the outer islands (Harris \& McKenny 1999). Clearance of original vegetation 

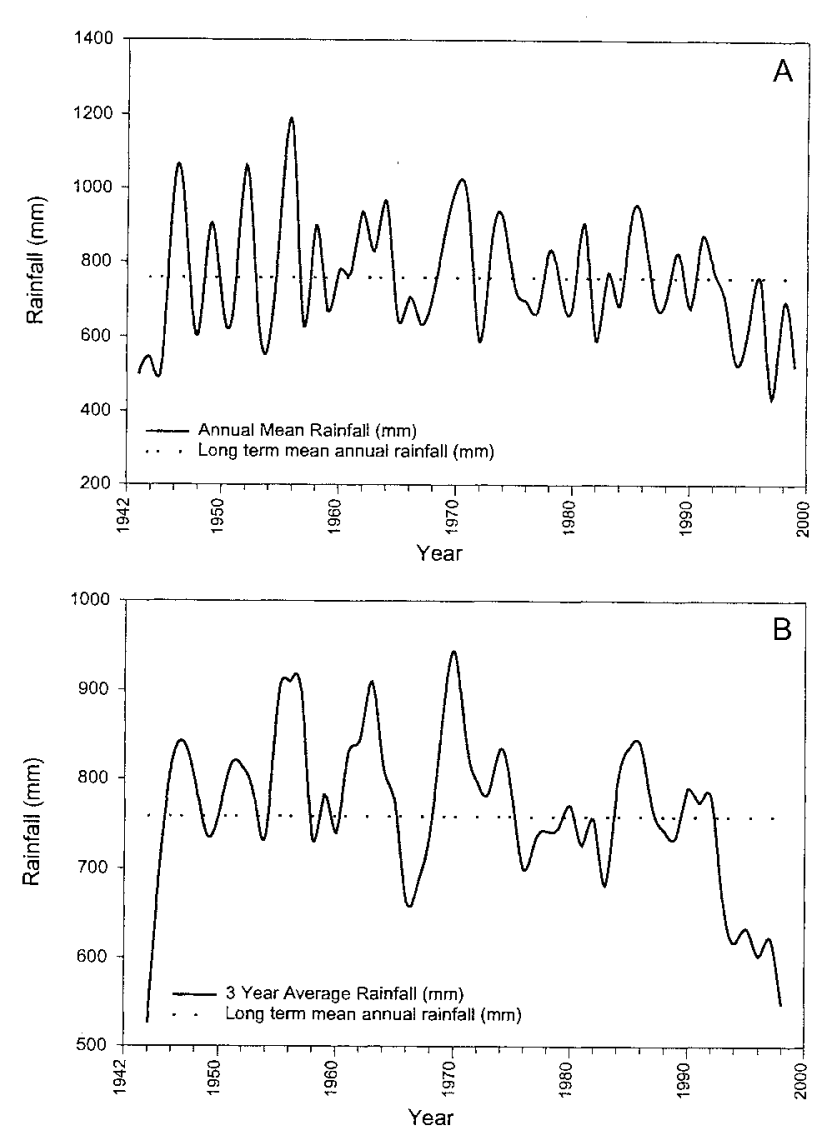

FIG. 3 - (A) Average annual rainfall at Flinders Island airport 1943-99, showing long-term mean annual rainfall; (B) The rolling three-year mean of annual average rainfall, indicating a cumulative moisture deficit in recent years.

by fire and axe was underway on many of the larger outer islands from the earliest years of the 19th century. East Kangaroo was still densely wooded in the 1820s. Clearing was probably inefficiently carried out, with the likely consequence that native shrubby vegetation persisted for some years. The 100 head of stock reported for the island in 1874 could have reflected this prevalence of rough pasture interspersed with low native scrub. The stocking rate varied between 500 and 700 sheep for much of the 1900s, and in January 2000 the number was around 500. Pasture grasses never needed to be sown, but Robin Walker (pers. comm.) claims that reseeding occurred by transporting to the island bundles of Poa which had been cut from roadsides on Flinders Island.

The stocking rate on the island has been consistent but, with declining rainfall since 1992 and a parallel decline in vegetable biomass production, there has been increasing pressure on the fast-dwindling pasture. The decline in pasture production below replacement rates occurs as rainfall continues below the recorded average. With a flock of sheep in a finite area putting relentless pressure on a decreasing resource, the impact becomes compounded until stock begin dying. Stock were deliberately destroyed before this point was reached.

There is no knowledge of what seed may be dormant in the soil, awaiting rain, or what proportion of any such seed might be exotics, or particularly undesirable ones. Widespread natural vegetation recovery cannot be expected because of the prolonged drought period, the loss of soil and the number of undesirable exotics which could take aggressive advantage of lack of normal vegetation cover. Some species which typically occur on the limestone soils of the Furneaux Group (Underewood 1998) are absent from the island, suggesting the possibility of local extinction due to land use activities.

Cape Barren gosling counts over the years reinforce the importance of the island as one of the main breeding islands in the Furneaux Group. Over a period from 197898 the island had an average gosling count of 427 (the third ranked island in the nine islands subject to census). Although the count fluctuates from season to season, a dramatic fall in numbers was recorded, from 403 in 1997 to 299 in 1998, and thence to 85 in 1999. Counts on other censused islands, by contrast were $10 \%$ up on the 1997 counts in 1998 and only $10 \%$ down on the long-term average (Hocking 1999). It is clear that the sudden decline in gosling numbers reflects the decrease in vegetation cover on East Kangaroo Island, which has resulted from a combination of low rainfall and grazing pressure. Once the vegetation has recovered, it is expected that the island will resume its importance as Cape Barren Goose breeding habitat.

Soil loss began to occur in the 1999/2000 summer. Large wind-borne soil plumes above East Kangaroo Island were observed from Flinders Island. The soil loss is from alkaline sands on the rookery. These sediments are of aeolian origin, so can become easily mobilised by the wind in the absence of vegetation. Bird bones are exposed on the rookery surface, indicating loss of soil. These are normally well below the surface in the burrows (Dr I. Skira, pers. comm.).

\section{Reversing the Vegetation Decline}

The island is distant from natural sources of plant propagules, apart from bird-dispersed Boxthorn (Lycium ferocissimum) (Peter 2000).

The management aims for the island will determine the revegetation plan. The principle aims are: (1) to protect and enhance the island as a Cape Barren Goose breeding island and (2) to protect the native plants of conservation significance. The other identified values of the island (Jennings 1976) are geological features of granodiorite emplacement, including well-defined foliation, oriented xenolithic rafts, dykes and cobweb fracture patterns with aligned feldspar phenocrysts. These are all hard rock features of the coast, which will be unaffected by any conceivable management regime on the island. There is no management plan for the island. Generic goals for Nature Reserve management are specified in the National Parks and Reserved Land Regulations 1999.

The recovery programme is advised to use the species shown in table 2, which can be readily propagated and have the best chance of survival.

Revegetation work should proceed over a winter period when humidity is higher and there is less likelihood of the soil being dry for extended periods. The island has no known vegetation conservation values inland of the immediate coast. As the island is potentially one of the best goose breeding islands and is already a Nature Reserve, planning for rehabilitation should allow for open grassy areas. An appropriate pasture seed mix (see appendix 2) is 
TABLE 2

Native plant species recommended for revegetation work on East Kangaroo Island, their likelihood of being native to the island and the suggested source for propagation material

\begin{tabular}{llll}
\hline Species & Common name & Faithful to native flora & Source of propagules \\
\hline Allocasuarina verticillata & Sheoak & $\mathrm{B}$ & airport \\
Rhagodia candolleana & Climbing saltbush & $\mathrm{A}$ & island \\
Tetragona implexicoma & Ice plant & $\mathrm{A}$ & island \\
Callitris rhomboidea & Oyster Bay pine & $\mathrm{C}$ & Badger Island \\
Leptospermum laevigatum & Coastal tea tree & $\mathrm{C}$ & Badger Island \\
Leucopogon lanceolatus & Shade beard heath & $\mathrm{C}$ & Badger Island \\
Alyxia buxifolia & Sea box & $\mathrm{C}$ & Furneaux Islands \\
Acacia sophorae & Coast wattle & $\mathrm{C}$ & Furneaux Islands \\
Poa poiformis & Coastal soft tussock & $\mathrm{A}$ & island
\end{tabular}

$A=$ occurs on the island, $B$ = previously recorded from the island, $C$ = possibly occurred on the island.

proposed, to attain rapid cover, with expected soil-binding and drought-hardiness benefits. The grass seed should be partitioned into two lots with one lot being sown in April 2001. Sowing seed over two seasons will lessen the risk of establishment failure. Sheoak establishment should begin early, because this will be extensive and will be relied on for shelter belts as the trees attain maturity. Areas proposed for this treatment (fig. 4) would include a belt aligned northsouth along the ridge at the western end of the island in addition to scattered copses. The sheoak should be cut as brushwood on Flinders Island and laid crisscross on the ground and on the Austrostipa stipoides tussocks. The drying branches will provide protection and some shade for the seedlings, which should emerge in large numbers from the cones. Other copses of sheoak would be treated in the same way - by laying cut branches heavily laden with ripe cones down on the ground and leaving them.

Copses of Leptospermum laevigatum, Callitris rhomboidea and Leucopogon lanceolatus would be situated through the central and eastern parts of the island from slash of material imported from Flinders Island and Badger Island. The slash would be laid down loosely over the ground in different orientations, then cone clusters of Oyster Bay pine collected from Badger Island would be dispersed over the top of these heaps.

The boxthorn must be kept in check and gradually eradicated. The island should be partitioned into operational units. Boxthorn eradication should be tried using Tordon ${ }^{1 M}$ granules, which can be applied at the rate of $35-45 \mathrm{n} / \mathrm{m}^{2}$. The more isolated specimens of boxthorn would be treated first. An alternative treatment is by injection of Velpar ${ }^{(B)}$ into the soil. Such treatment requires follow-on rain to mobilise the poison, death follows from 6-18 months. This chemical is highly mobile in the soil and in near coastal situations could leach out into littoral herbfields. The treated bushes should be left intact because physical removal may disturb the soil. The dead boxthorn cages are useful for assisting with the establishment of other plants, especially the climbing succulents Tetragonia implexicoma and Rhagodia candolleana. Poa poiformis clumps need to be transported to the island in large quantities and used for dividing and direct planting into the rookery soils. Vigorously growing tussocks, ideally having attained semimature growth after burning should be top-trimmed and planted in mid to late winter. Tetragonia implexicoma needs

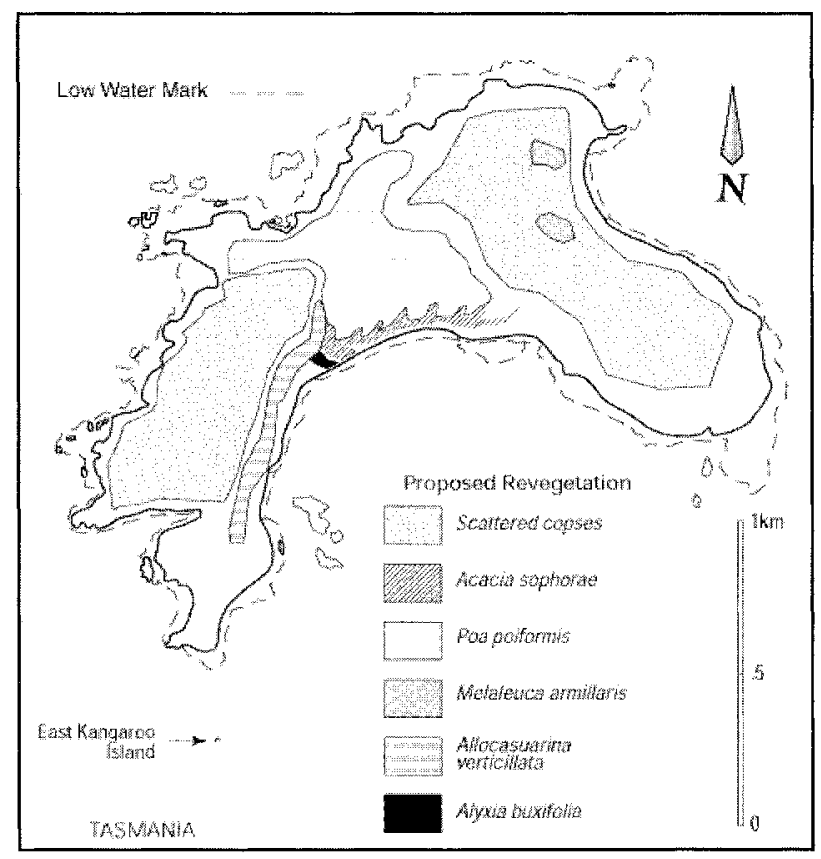

FIG. 4 - Map showing the proposed revegetation of East Kangaroo Island.

to be established throughout the rookery area at suitable intervals so that it will spread throughout the rookery and provide a good salt/drought tolerant cover.

The Department of Primary Industries, Water and Environment is committed to long-term land use for this island as a Nature Reserve and recognises that its primary management goal is for Cape Barren Goose breeding. This goal can be achieved, either with the development of tracts of pasture which could be maintained in conjunction with sheep-grazing, or by revegetating the island with native species and restoring the supposed pre-European habitat as faithfully as possible. The rehabilitation measures proposed in this paper do not compromise either course of action in the longer term. If the island is to retain some exotic pasture (and maintenance of grazed exotic pasture is likely to support a higher population of breeding geese) then it will coexist with shelter belts and copses of native trees and shrubs. Appropriate pasture grass seed is readily available and there is an urgent need to consolidate the soil. The 
recommended mix (appendix 2) includes only species which are already established in the outer islands and are unlikely to threaten other values on the islands.

If stock are again permitted on the island, the allowable stocking rate will need to be reviewed. Some of the rookery area and areas regenerating to scrub would need to be fenced. The first priority is to rest the island for five years to allow an assessment of the vegetation recovery.

\section{ACKNOWLEDGEMENTS}

We thank W. Warren, R. Purdon and S. Underwood for assistance with logistics and field data collection. We had helpful discussions with James Luddington, Chris Arthur and Neil Watson. Colleagues in the Nature Conservation Branch made useful comments on a draft, especially Greg Hocking and Irynej Skira. Nicki Chilcott assisted with the graphs. Alex Buchanan of the Tasmanian Herbarium determined some of the species collections and confirmed others, while David Ponsford of the National Herbarium of Victoria assisted with records from his institution's collection. Tim Rudman provided advice on weedicide treatments. Bob Reid, Senior Agronomist of the Department of Primary Industries, Water and Environment was most helpful in advising on appropriate pasture grasses, as was Barry Hardwick of Greening Australia for advice on native vegetation re-establishment. We dedicate this paper to the memory of Derek Smith OAM who helped to pioneer Cape Barren Goose conservation.

\section{REFERENCES}

Arthur, C., 1997: Memorandum to Manager Nature Conservation Branch. DPIWE file 06-93-22

BuCHANAN, A., 1999: A census of the vascular plants of Tasmania. Tasm. Herb. Occ. Publ. 6. 3rd edn. Hobart.

CAmpbeLl, J., 1828: Account of the groupe of islands situated in Bass Strait generally known in the charts by the name of Furneaux Islands. Hobart Town August 1828. (MS in Mitchell Library, Sydney.)

FRIEDEL, M.H., 1977: The determination of an optimum sampling technique for biomass of herbaceous vegetation in a Central Australian woodland. Aust. J. Ecol. 2: 429-433.

Friedel, M.H. \& Bastin, G.N., 1988: Photographic standards for estimating comparative yield in arid rangelands. Aust. Rangeland J. 10(1): 34-38.

Friedel, M.H., Chewings, V.H. \& Bastin, G.N., 1988: The use of comparative yield and dry-weight-rank techniques for monitoring arid rangeland. J. Range Manage. 41(5): 430435.

Griffiths, C.J., 1927: Letter from Mr Claud J. Griffiths, Whitemark to the Hon. J. Allen Guy, January 1927. Archives Office of Tasmania reference AB 567/291.

HaRley, H.B., 1974. Letter from George F. Harley per H. Barbara Harley to The Secretary Lands and Surveys Department. Archives Office of Tasmania reference AB 567/291.

Harris, S. \& McKenny, H., 1999: Preservation Island, Furneaux Group: two hundred years of vegetation change. Pap. Proc. R. Soc, Tasm. 133(1): 85-101.

Hocking, G., 1999: Report on Cape Barren Goose Egg Harvesting in the Furneaux Group. Unpubl. rep. Parks Wildl. Serv., Hobart.

Jennings, D.J., 1976: Proposed East Kangaroo Island Nature Reserve. Memorandum to the Chief Geologist. DPIWE file 50-24-75.
Mooney, P., 1985: East Kangaroo Island Nature Reserve. Memorandum 12 February 1985. DPIWE file 50-2476.

Murray-Smith, S., 1979: MISSION TO THE ISLANDS. The Missionary Voyages in Bass Strait of Canon Marcus Brownrigg, 1872-1885. Cat and Fiddle Press, Hobart.

PearSe, R.J., 1975: Cape Barren Geese in Tasmania. Biology and Management to 1975. Wildl. Div. Tech. Rep.75/1. NPWS Tasmania.

Peter, J.M., 2000: Birds and Boxthorn. Vict. Nat. 117(2): 6366.

Plomley, N.J.B., 1987: WEEP IN SILENCE. Blubber Head Press, Hobart.

SIM, R. \& GAIT, P., 1992: SOUTHERN FURNEAUX ISLANDS ARCHAEOLOGICAL SURVEY: Stage two of the prehistoric and historic archaeological site recording project in the Furneaux Group, Bass Strait, Tasmania. Tasmanian Environment Centre, Hobart: 6-7.

Summers, S., 1998: Memorandum to Director, Resource Management and Conservation. DPIWE file 06-93-22.

ThOMAS, I., 1861: DORSET 4: Surveys and notes. Mapping Branch, Department of Primary Industries, Water and Environment.

UNDERWOOD, S., 1998: Synecology and conservation of vegetation on aeolian calcarenite, Flinders Island, Bass Strait. Unpubl. B.Sc. (Hons) thesis, Univ. Tasm.

(accepted 30 October 2000)

\section{APPENDIX 1}

Higher Plant Census For East Kangaroo Island. Nomenclature follows Buchanan (1999). (I) following species name = introduced in Tasmania; (i) = new introduction of species formerly extinct on East Kangaroo Island. $\mathrm{MEL}=$ collections in the National Herbarium of Victoria, with collection numbers.

\section{DICOTYLEDONAE}

AIZOACEAE

Disphyma crassifolium

Tetragonia implexicoma

APIACEAE

Apium insulare

A. prostratum

ASTERACEAE

Actites megalocarpa

Arctotheca calendula (I)

Carduus tenuiflorus (I)

Cotula coronopifolia

Euchiton involucratus

Hypochoeris radicata (I)

Olearia axillaris

Sonchus asper (I)

Pseudognaphalium luteo-album

Vellereophyton dealbatum (I)

BRASSICACEAE

Cakile maritima (I)

CAMPANULACEAE

Lobelia alata

Wablenbergia sp.

CAPRIFOLIACEAE

Sambucus gaudichaudiana

CASUARINACEAE

Allocasuarina verticillata (i)

CARYOPHYLLACEAE

Cerastium glomeratum (I) 


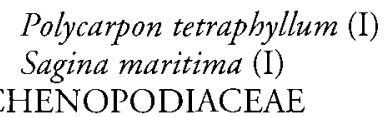

CHENOPODIACEAE

Atriplex cinerea (I) (Whinray, MEL 530200)

Atriplex prostrata (I)

Chenopodium glaucum (I)

Chenopodium murale (I)

Chenopodium pumilio (I)

Rhagodia candolleana

Sarcocornia quinqueflora

Threlkeldia diffusa

CARYOPHYLLACEAE

Colobanthus apetalus (Whinray MEL 530190)

CONVOLVULACEAE

Calystegia soldanella

Dichondra repens

CRASSULACEAE

Crassula sieberiana ssp tetramera

EUPHORBIACEAE

Euphorbia paralias (I)

FABACEAE

Medicago lupilina (I)

Medicago polymorpha (I)

Melilotus indica (I)

Trifolium dubium (I)

Trifolium repens (I)

\section{GENTIANACEAE \\ Sebaea albidiflora \\ GERANIACEAE}

Erodium cicutarium (I)

Erodium moschatum (I)

Geranium molle (I)

Geranium potentilloides

Pelargonium australe

LAMIACEAE

Marrubium vulgare

MALVACEAE

Malua sylvestris (I)

MYOPORACEAE

Myoporum insulare

MYRTACEAE

Eucalyptus lehmannii (I)

ONOGRACEAE

Epilobium billardierianum

Epilobium sarmentaceum

OXALIDACEAE

Oxalis perennans

PLANTAGINACEAE

Plantago coronopus (I)

POLYGALACEAE

Comesperma volubile

POLYGONACEAE

Acetosella vulgaris (I)

Rumex brownii

PORTULACEAE

Calandrinia calyptrata

Montia australasica

ROSACEAE

Acaena novae-zelandiae

Acaena pallida

RUBIACEAE

Coprosma repens (I)

RUTACEAE

Correa alba

\author{
SOLANACEAE \\ Lycium ferocissimum (I) \\ Solanum nigrum (I) \\ URTICACEAE \\ Urtica incisa \\ Urtica urens (Whinray MEL 534002)
}

\section{MONOCOTYLEDONAE}

CYPERACEAE

Carex pumilio

Eleocharis acuta

Isolepis nodosa

Isolep is subtilissima

JUNCACEAE

Juncus bufonius

LILIACEAE

Bulbine semibarbata

POACEAE

Austrodanthonia racemosa

Austrofestuca littoralis

Austrostipa stipoides

Bromus diandrus (I)

Bromus hordeaceus (I)

Catapodium rigidum (I)

Dichelachne crinita

Holcus lanatus (I)

Hordeum murinum ssp glaucum (I)

Hordeum murinum ssp murinum (I)

Lagurus ovatus (I)

Lolium loliaceum (I)

Lolium rigidum (I)

Parapholis incurva (I)

Poa poiformis

Polypogon monspeliensis (I)

Spinifex sericeus

Vulpia bromoides (I)

\section{APPENDIX 2}

To re-establish pasture it is recommended that the following mix be sown in early May on all areas except the area mapped as Austrostipastipoides grassland. Application rates are shown:

$\begin{array}{ll}\text { Lolium perenne cult. "Fitzroy" } & 3 \mathrm{~kg} / \mathrm{ha} \\ \text { L. perenne cult. "Vic" } & 4 \mathrm{~kg} / \mathrm{ha} \\ \text { Dactylis glomerata cult. "Tecapo" } & 3 \mathrm{~kg} / \mathrm{ha} \\ \text { Medicago sp. "Medic" } & 4 \mathrm{~kg} / \mathrm{ha} \\ \text { Trifolium subterraneum cult "Trickala" } & 4 \mathrm{~kg} / \mathrm{ha}\end{array}$

The clover and medic should be treated by lime pellet innoculation to ensure appropriate Rhizobium is attached to the seed of each species. The seed should be broadcast by a hopper from a four-wheel-drive motorcycle, using community assistance if available. If logistically and economically feasible, in the first spring after sowing seed, some sheep, say 200, could be shipped over to graze the grass down to $75-100 \mathrm{~mm}$ to encourage tillering. The sheep should be moved off and the pasture rested before another grazing period the following year. Otherwise, reliance must be placed on Cape Barren Geese to do this. There can be no expectation that stock can be continuously on the island for at least five years, while basic revegetation work is carried out. 